\title{
THE RUSSIAN REVOLUTION AND THE LABOUR MOVEMENTS OF AUSTRALIA AND NEW ZEALAND, I9I7-1922
}

The Bolsheviks saw their revolution, not as merely Russian, but as the opening act in a great drama of international socialist revolution. This vision, dazzling in itself, mingled with Russian reality, evoked responses in the Australian and New Zealand labour movements. To these countries, the Russian revolution came as part accomplished fact, part world myth, an astonishing sublimation of the enforced and sordid internationalism of suffering on the battlefields of the world war. As such, it was peculiarly disturbing to labour movements which had been, in the main, traditionally cautious and self-sufficient, resistant to both dreams and doctrines. But even Australian and New Zealand labour could not live by bread alone. Was the Russian revolution relevant? This was the basic question, and, at first, it went to the core of local conflicts and indecisions. At first, this question seemed to mean - were revolutionary concepts relevant to Australian and New Zealand conditions, in a situation of imminent world revolution. Was labour to pursue doctrinaire, militant and revolutionary socialism, or welfare-state reformism? 'This fundamental alternative was, of course, not absent before the Russian revolution, but that revolution posed it with a realism, bluntness and urgency never experienced before. Yet hardly had Australian and New Zealand labour confronted with this imperative, when its terms began to change as circumstances narrowed the challenge represented by Russia. Was the Russian revolution relevant? By I 920 this question had come to mean - would Australian and New Zealand labour accept Russian methods, theories and direction?

At the time of the March 1917 Russian revolution, the Australian labour movement was singularly open to radical influences. Bitter conflict between politicians and party opinion over the issue of conscription had just wrecked the Australian Labor Party, which lost, in consequence, control of the Federal, and New South Wales State, governments initially gained in 1910. The circumstances of the split produced an envenomed reaction, in part associated with and intensifying a pre-existing anti-political swing, in general discrediting the standards and methods of the politicians who had supported con- 
scription. ${ }^{1}$ Its political expression crippled by the split, reduced to minority status, labour adopted minority values and tactics. The political tradition associated with the great conscriptionist betrayal reformism, "State Capitalism", opportunism, vote-catching, "the fetish of leadership" - was renounced, branded as non-labour. Labour's spokesmen insisted that the movement must return to first principles, to a rank and file idealism, both unionist and socialist, akin to that associated with the formation of the Labor Party in $189 \mathrm{I} .{ }^{2}$ According to H. E. Boote, editor of the Australian Worker, labour had emerged from its tribulations reborn, purified, at last master of its own destiny, now fit and able to launch the Co-operative Commonwealth. ${ }^{3}$ This sweeping reaction, later expressed in attempts to revolutionise the reformist A.L.P. objective, swung labour opinion towards socialist militancy, and thus into harmony with a Russian revolution conceived as "the downfall of ancient despotisms and the uprising of the downtrodden multitude..."4 The linkage is plain in the argument that the Russian worker "was strong because he had no Labor politicians to advise him, and... had a firm hold on a few great principles". ${ }^{5}$ Associated with this surge of internal radicalism went a more general discontent, produced by the increased cost of living and apprehension of world-wide change and ferment engendered by the war. This too predisposed Australian labour to welcome revolution in Russia as harbinger of some counterpart or variant in every land. ${ }^{6}$

The development of the revolution in the months following March brought it further into harmony with the temper of Australian labour. Russian movements against war and towards a general peace were the most potent positive factors in enlisting the sympathy and admiration of influential labour opinion. ${ }^{7}$ A labour movement identified with anticonscription saw in the Russian revolution a movement with aims similar to its own. This feeling was intensified by the growing hostility

${ }^{1}$ Labor News (Sydney), 7 Dec. I918.

${ }^{2}$ Ibid. 25 Jan. I6 Nov. I918, 8 Feb. I919. See P. J. O'Farrell, The Australian Socialist League and the Labour Movement, I887-I 89I, in: Historical Studies, Australia and New Zealand, Vol. 8. No. 30, May 1958, pp. I $52-165$.

${ }^{3}$ Australian Worker (Sydney), 22, 29 March, 3 I May 1917.

4 Ibid., 7 June I917.

${ }_{5}^{5}$ Worker (Brisbane), 2 I June 1917.

${ }^{6}$ Social Democrat (Sydney), 8, 22 Feb. 1918; Labor News, 2, 9 Nov. 1918; Australian Worker, 8 June 1917 .

7 Australian Worker, 3, 3I Jan. 1918; Social Democrat, Is March 1918; Worker, 31 Jan. I9I8; International Socialist (Sydney), 2 June I917; Socialist (Melbourne), 30 March, 25 May 1917, I1, I8 Jan., I4 June I918; Commonwealth Parliamentary Debates, Vol. LXXXIII, p. 3 I 72 (Anstey), Vol. LXXXVI, p. $787^{8}$ (Considine); Report of the Seventh Commonwealth Conference of the Australian Labor Party. Opened at Perth June 17 , 19I8, Melbourne 1918, pp. 8-1 I. 
towards Russia displayed by labour's enemies. Prime Minister W. M. Hughes, for instance, stated in June 1917, that he would prefer a vigorously pro-Allies Czarist tyranny, to a non-combatant revolutionary Russia. 1

Given these initial predispositions, Australian labour was deeply influenced in its estimate of the Russian situation by the enthusiasm, analyses and opinions of Russian socialists living in Australia. Just prior to the war, a small number of exiled Russian revolutionaries had come to Australia, joining local socialist organisations and forming Russian Associations. Upon the outbreak of revolution, their formative influence was felt not only informally, and through the increased activities of Russian Associations, but also through the widespread circulation of their views, as solicited by labour and socialist organisations. The local Russian convictions immediately following March were that the Soviets were "the true revolutionary elements" in Russia, and that merely the first phase of the revolution had occurred - a second, labour versus capitalism, being imminent. These views were accepted generally within the labour movement. ${ }^{2}$

Russian opinion continued to be influential in the years that followed. It acquired greater immediacy as those who had returned from Australia to Russia sent back reports of the developing revolutionary situation. The most important Russian influence was that exercised by Peter Simonoff, appointed Bolshevik Consul-General for Australia early in 19r8. Simonoff had come to Australia in 1912, and had maintained contact with the Russian revolutionary movement. ${ }^{3} \mathrm{Al}-$ though refused official recognition as consul, a refusal used by Russian Associations to take vanguard action in the labour movement, Simonoff engaged in a tremendous amount of pro-Bolshevik writing and lecturing. In 1918 , he had one clear message - "emancipate yourself in Australia". This would assist Soviet Russia by frustrating capitalist attempts to overthrow it. ${ }^{4}$ With bis call to emancipation, most of his labour audience were in general agreement, but the vital and divisive question was, how could this be carried out?

The relative unanimity of the Australian labour movements' welcome to the revolution's destructive aspects as expressed in March continued for some years to mask fundamental differences on the

${ }^{1}$ Socialist, 13 July 1917 ; Worker, 26 July 1917.

${ }^{2}$ Socialist, 23 March 1917; Worker, I9 March, 10 May 1917; A ustralian Worker, 22 March, 21 June 1917 ; International Socialist, 2 June 1917.

${ }^{3}$ Socialist, 2 Nov. 1917, I Feb., 22 March 1918; Worker, 3I Jan. I918; Social Democrat, I Feb. I9I8.

4 International Socialist, 6 April 1918. 
questions raised by November. Domestic issues - in particular the I9I 7 strike and the second conscription referendum - played an important part, together with the lack of Russian news, in reducing to excessive simplicity and vague generality the Australian labour view of the Russian revolution. Prior to, and at the time of the November revolution, Australian labour was so totally absorbed in the 1917 strike and the conscription campaign that the revolution escaped its attention. ${ }^{1}$ The result was a gap in consciousness. For some considerable time, the majority of Australian labour commentators thought of the Russian revolution in terms of that of March, that is of hopeful, undefined socialist idealism. The actualities of Bolshevik revolution took long to grasp.

Most labour observers appreciated the possible international implications, the potential mass "psychological" impact of Russian revolution. Most, to some degree, accepted the revolution as a challenge to Australian labour to stand by its principles. ${ }^{2}$ But there were different understandings of what the Russian revolution meant, and what labour's principles were. A.L.P. spokesmen took the revolution to mean, in some vague and confused way, the installation of social democracy. ${ }^{3}$ The Australian Socialist Party took it to mean the triumph of revolutionary socialism, seeing in Russia the actualisation of its own doctrinaire theories, and confirmation that world revolution would be on those lines. ${ }^{4}$ This was of no immediate significance. The A.S.P. and its predecessors had been taking similar lessons from various world events since 1887 when the first socialist group had been formed, and its reaction to the Russian revolution was, initially, unique only in degree. While the A.S.P. stressed internationalism, A.L.P. supporters, acutely sensitive to the Australian situation, tended to be suspicious of Russian achievement. They argued that, purged of treacherous leaders, and inspired by its industrial section, the A.L.P. was a potentially revolutionary force. ${ }^{5}$

As the revolution survived throughout I9I8, these attitudes were developed and clarified. The A.S.P. urged that Bolshevik revolution successfully proved that organised industrial socialists must overthrow parliamentary government and set up an industrial democracy. It suggested in May 1918 the formation of Australian soviets. ${ }^{6}$ How-

1 Worker, Is Nov., 27 Dec. 1917, 31 Jan. I91 8.

2Ibid., 22 March, 5 July 1917; Australian Worker, 7 June 1917; International Socialist, 2 June 1917; Socialist, 22 March 1918.

${ }^{8}$ Worker, 3 I Jan. I9I 8 .

- International Socialist, 2 June, 4 Aug. 1917, 9 March 1918.

- Australian Worker, 22, 29 March, 28 June I9I 7.

- International Socialist, 6, 27 April, I I, I8 May, I June I9I8. 
ever, the A.S.P.'s attitude, which was also faction-political, did not evince any response from the industrial revolutionaries. The adherents to the views held by the proscribed Industrial Workers of the World paid little if any attention to Russia, being satisfied with the direct actionist and anti-political tradition of the I.W.W. Their standpoint was that the I.W.W. were the Australian Bolsheviks, and that was that. ${ }^{1}$ Nor were the more moderate champions of a rejuvenated A.L.P. impressed by the detail of Russian example. H. E. Boote denied that the violence of the Russian revolution was relevant to Australia where a constitutional and peaceful transference of power would take place. ${ }^{2}$

How did the Russian revolution relate to Australian labour realities? Its most significant general impact lay in its impingement on the spirit, aspirations and conscience of the labour movement as a whole. Its particular and detailed relevance lay in its appeal, not merely to a few revolutionary doctrinaires and fanatics, but, particularly after 1919, to the growing forces of pro-political militant industrialism centered on the One Big Union movement and the Sydney Labor Council.

It was not the Russian revolution which awakened an international outlook among Australian labour, but the war. In 1918 , it was not the Russian revolution in itself, as Russian, which commanded most attention, but the revolution as an international portent. From the middle of the year the situation in Germany, central to Marxist theory, attracted increasing interest. With the end of the war, and revolution in Germany, the world seemed to have entered a state of unparalleled crisis. From this crisis international revolution could issue, and Australian radicals saw 1919 as the year of decision. ${ }^{3}$ This conviction resulted in an extraordinary heightening of emotions and tensions within the labour movement, the development of a crisis mentality. It was a development that acted as a forcing ground for the ideas and attitudes, not only of the proponents of world revolution, but by way of challenge and interaction, it affected all groups within the labour movement. The hope, or threat, of world revolution, forced all groups to examine and define their positions. This atmosphere of crisis was intensified by repressive governmental measures taken against proBolshevik activity and coinciding with the peak of the revolutionary wave in Germany. The crisis mentality, product of reaction from war, orientated towards the prospect of world revolution, was, in a sense, not dependent for sustenance on actual revolution in Russia, particularly as Germany was believed to be the key point, and some observers

1 Solidarity (Sydney), I9 Jan., 23 March, I June, I4 Dec. I91 8 ; Socialist, 6 July I 918.

- Australian Worker, 9 May 1918.

-Australian Worker, 30 Jan. I919; International Socialist, 4, 18 Jan. I, 8, 22 Feb. I919. 
were already unhappy about the actual degree of Russian achievement. ${ }^{1}$ Nevertheless, the Russian revolution had succeeded, and still existed, attributes of the greatest importance when other revolutions failed. Unquestionably it was the Bolsheviks' success and continued existence which attracted Australian labour. Success gave the Russian revolution enormous prestige, made labour reluctant to condemn its excesses, and demonstrated the practical applicability of militancy.

The A.S.P. learnt little from Bolshevism, merely interpreting it to suit and bolster its own traditional position. Militant industrial and progressive groups within the Labor Party adopted a similar attitude equating Bolshevism with the realisation, or partial realisation of their own ideals. Thus, Russia was seen as a pioneering lesson in democratic majority government - "out of the population of Russia - one hundred and eighty millions - at least one hundred and sixty millions are Bolsheviks."2 There was a marked tendency to romanticise Russian achievements, to identify Bolshevism with all labour's ideals and aspirations, a vague Utopian socialism, the coming of a Golden Age, practical Christianity, complete emancipation from poverty, ignorance and all human ills. ${ }^{3}$ The widespread pro-Russian sympathies of the labour movement were in large part based on the simple proposition that the Bolsheviks were fighting capitalism and so was the A.L.P. ${ }^{4}$ "Laborites, Socialists, Communists, Bolsheviks are all at one in their desires, their aims and their aspirations". ${ }^{5}$ And given this equation, many in the labour movement were deeply impressed by the fact that "while others had talked Socialism, the Russians had acted..."6 To side with Russia was to side with success, and with the future.

In this surge of emotional enthusiasm, the facts of Bolshevik revolution were lost among vague dreams, wishful thinking and local grievances. The desire to side with Russia, to participate in the benefits of world revolution, issued in a superficial and indeed spurious internationalism based on the proposition:

"The Labor Movement of Australia and England is the Socialist Movement of France, Germany and Austria and the Working Class Movement of Russia."7

1 Proletariat (Sydney), I Feb., 22 March 19x9; International Socialist, 3 May, rgrg; Labor News, 8 Jan. rgrg.

2 Worker, 21 Nov, 1918, 13 March, 17 July 1919; C.P.D. Vol. LXXXIII, p. 3082 (Considine); Labor News, 2 I Dec. 1918.

'Labor News 18, 25 Jan., 7 June 1919; Worker, I4 Feb., 12 Sept. 1918, 16 Jan. I919.

- Worker, 13 Nov. 1919.

5 Labor News, 18 Jan. I919.

- Socialist, 3 I Jan. I9I9.

? Worker, 20 June Igi 8 . 
However misconceived, the sense of international involvement, expressed in the argument that Australia must keep up with the advanced nations, lent urgency and determination, even exaltation, to Australian militancy. Here was a chance to get out of the rut of little things. What lessons did Europe offer? At the end of 1918, industrial militants within the A.L.P. demanded unity, particularly industrial solidarity, in the face of imminent world crisis. The European, and particularly the Russian situation demonstrated, in their eyes, the success of political activities directed and controlled by militant and unified industrial organisations. ${ }^{1}$ Arthur Rae, editor of Labor News, was stating this viewpoint when he contended that the universal ballot, plus industrial pressure, perhaps organised through Soldiers' and Workmen's Councils, would open the way to a peaceful, legal and complete change in the ownership and control of wealth production. ${ }^{2}$ Already, by the end of I9I 8 , the One Big Union movement testified to the determination of industrial militants to "revolutionise our Parliamentary platforms". ${ }^{3}$

Until I9r9 most A.L.P. politicians and moderates avoided the Russian issue. They were deeply disturbed by the revolution, as it appeared to testify to the success of militant policies, and acted as an inspiration to Australian militants. Yet the success of the Bolsheviks, European uncertainty, and the militant temper of much of the labour movement made the politicians and moderates cautious and conformist. In consequence "Hands off Russia" and similar sentiments became general throughout the whole labour movement. ${ }^{4}$ But when militants expressed the conviction that the whole future of Australian democracy was bound up with Bolshevik success, ${ }^{5}$ the implications were such that moderates could not agree.

By the early months of 1919 , it was apparent to the politicians and their supporters, particularly in N.S.W., that they must make a stand. The "world crisis" attitude, the challenge of the O.B.U. (the One Big Union), the industrial militants' determination to capture and revolutionise the A.L.P., all in the context of approaching elections, made militancy a real and vital threat. Storey, Dooley, Catts and Loughlin led the politicians in a reassertion of the virtues of moderation, con-

1 Worker, 7, 14, 21,28 Nov., 5 Dec. I918; Labor News, 16, 30 Nov. I918.

2 Labor News, 9, 16 Nov., 7 Dec. I91 8.

${ }^{3}$ Australian Worker, 19 Sept. 1918. Also Socialist, 6 Sept, 1918; Worker, 26 Sept. 1918; Labor News, 23 Nov. I918; Social Democrat, 24 May 1918.

${ }^{4}$ Labor News, 5 April, i 7 May, I4 June 1919; Australian Worker, I May 1919; Worker, 26 June 1919; Official Report of the Eighth Commonwealth Conference of the Australian Labor Party. Opened at the Trades Hall Sydney, June I 8th I919, Hobart x919, p. 81.

5 Labor News, 17 May I919; International Socialist, 25 Oct. I9 9. 
ciliation and gradual change. ${ }^{1}$ Their arguments took root in the growing hostility of the Australian Workers' Union to the O.B.U. ${ }^{2}$ and in the strengthening conviction, as the Russian and European situations clarified, that Australian labour had nothing practical to learn from Russia. ${ }^{3}$ Their enthusiastic championing of Russia became a major liability to the militants in what was essentially a domestic issue, the struggle for power. A hostile daily press was using the term Bolshevism, equated with revolutionary lawlessness and atrocities, against the A.L.P. Bolshevism was therefore an obvious electoral liability, which the politicians regarded not only as such, but as a useful weapon with which to repulse a challenge to their power. What were the real issues, aside from those of personal power? Certainly there was no question of any attempt at close imitation of Bolshevik Russia. The Labor politician J. H. Catts, and Arthur Rae, taking opposed positions, saw the same essential issue at stake. In Rae's words:

"... the question is whether Labor is to be a middle-class party, with a platform of harmless palliatives, in order to capture Parliament by the aid of middle-class voters, or is it to be a working-class Movement with a platform of complete economic emancipation and reconstruction on a socialistic basis."4

This question was at the basis of militant attempts to persuade both Federal and N.S.W. Labor Party conferences in I919 to accept socialisation objectives. At both conferences these objectives were resisted by politicians on the grounds that any such changes might intensify charges of Bolshevism immediately prior to crucial elections. ${ }^{5}$ The defeat of the socialisation objective and the triumph of the moderates in executive elections at the N.S.W. conference led to a split, the industrial militants leaving the conference to form an Industrial Socialist Labor Party. ${ }^{6}$

Following the split, the N.S.W. executive and politicians opened a bitter attack on the secedets, denouncing them as "Bolsheviks and I.W.W.-ites", alien to the Australian spirit. The "vast difference between illiterate, downtrodden Russia and educated, democratic Aus-

1 Labor News, 8, is Feb., Is March, 26 April, 9 Aug. I9 19; Australian Worker, 27 March 1919; i April I919.

2 Australian Worker, I May, 5 June 1919; Worker, 20 March I919.

' Labor News, I March 1919; Australian Worker, 27 March, 10 April 1919; Worker, 8 May igra.

4 Labor News, 8, 22 March, I9 April 19 I9.

- Labor News, 5, 12 April, I4 June 1919; Report Commonwealth A.L.P. Conference I9 I9, op. cit. pp. 26-3I, 85.

- Labor News, I4, 21 June 1919; Australian Worker, 12, I9 June I9r9. 
tralia" was emphasised. The "Disruptionists" - and the O.B.U. was particularly singled out - were accused of wishing "to import the Soviet, Communism as it is practised up to date, and control it with an iron hand". ${ }^{1}$ Coming out in open denunciation of Soviet Russia as a tyranny, the N.S.W. A.L.P. attempted to turn the Bolshevik scare to its own advantage with claims that the failure of National Governments to implement reforms fostered Bolshevism, and that Labor was the only alternative if Bolshevism was to be averted. ${ }^{2}$

Up to this stage, it was true to say, in the words of an A.S.P. member:

"The Russian revolution is the popular theme of all working class organisations, even the orthodox labor party having gone Bolshevik, and each and all claim to be the national copy of the prototype."3

The N.S.W. split signalled the appearance of the Bolshevik revolution as an openly divisive issue. Although the split had been essentially a simple and traditional moderate-militant, politician-unionist conflict, the conservatives chose to parade the Bolshevik revolution as the crux of the matter. This, and their eruption into an anti-Bolshevism no less vehement than that of anti-labour forces, strengthened, by way of reaction, the links which the frustrated industrial militants saw between their own outlook and aims, and those of the Bolsheviks in Russia. To some minds the lesson was as simple as this:

"While the rank and file of the Labor movement are sympathetic with the Bolsheviki, the politicians and aspiring politicians are flerce in their denouncement."4

Their failure, and its circumstances, to capture the I9I9 conference, fostered among industrial militants a minority sect mentality and a further swing towards Russia, tendencies which found natural expression in a movement towards the formation of a communist party.

Bolshevism having become a contentious issue within N.S.W. labour, and Russian developments being less propitious than expected, those progressive A.L.P. supporters who had welcomed Russian revolution reassessed their position. A columnist in the Brisbane Worker began such an examination in October 1919. His starting point was that hitherto Russia's magnificent and inspiring experiment had been viewed by Australian labour with uncritical enthusiasm. How-

1 Labor News, 28 June, 26 July, 2, 9 Aug., 4 Oct. 1919.

Ibid., 9, 16, 30 Aug., 13 Sept., 4 Oct. 1919.

3 International Socialist, 27 Dec. 1919.

- Socialist, 3 Oct. 19 I9. 
ever, if it was to teach Australia anything, its weaknesses and difficulties must be assessed. The facts seemed to be these. Essentially Australia was a spectator. Everything depended on Europe, but revolution had not occurred there. The Russian revolution had not produced a social revolution. It was, in fact, antidemocratic, having not yet emancipated the working class. Australian circumstances were such that "we here may be in as progressively advanced a stage as our comrades in Russia". If anything was to be learnt from Russia, was it, perhaps, how not to go about making a revolution? Neither violence nor the Soviet system were necessary for Australian labour's emancipation. It must continue to rely upon democratic and peaceful industrial organisation and parliamentarianism, operated with the object of the gradual overthrow of capitalism and the establishment of socialism. ${ }^{1}$ By such argumentation progressive A.L.P. supporters were able to continue their acclaim of Russian achievement while insisting that it had no Australian relevance, save the most general inspiration. ${ }^{2}$

While political labour was moving away from the Russian revolution, industrial labour was moving closer to it. Close connections between industrial militancy, particularly in its O.B.U. form, and the spirit, theory and practice of the Bolshevik Revolution may be clearly seen developing throughout 1919. The first direct organisational reflection of the Russian revolution in Australia appears to have been an attempt, by industrial militants of O.B.U. persuasion to organise secret revolutionary socialist groups in N.S.W. in March I919. Their scheme was to adapt the system of soviets to Australian conditions and to permeate Labor and socialist organisations. ${ }^{3}$ Similar connections can be seen in Knowledge and Unity, the journal of the Queensland Russian Association. From the beginning of 1919, Knowledge and Unity was not only a Bolshevik propaganda organ, but virtually an O.B.U. journal as well. The linkage is apparent in such editorials as that entitled "All Power to the Soviets", which began, "In Australia the immediate necessity is to push the One Big Union scheme through to completion... The One Big Union is the instrument which will give the proletariat the means to do what they will."4 This Bolshevik-O.B.U. outlook while stressing organisations of the Soviet type and permeation of unions, was not anti-political, but politico-economic in an orthodox communist sense. It was, however, bluntly hostile to the A.L.P. as bourgeois reformist and arrogantly bureaucratic.

1 Worker, 23 Oct., 27 Nov., I I Dec. 1919, 8 April, 13, 20 May 1920.

Socialist, 14 Nov. 1919; Australian Worker, 16 Sept. 1920.

- Labor News, 29 March, ig July, 9 Aug. I9I 9.

- Knowledge and Unity (Brisbane), 20 Jan. I919. 
The essentials of this outlook were embodied in the leadership of the O.B.U. movement and the Labor Council of N.S.W. This group, in which J. S. Garden and A. C. Willis were prominent, had failed to capture the N.S.W. A.L.P. in June I9I9. Frustrated, disgruntled, radical, part opportunist, part idealistic, this group had sought a congenial ideology, which would be in accordance with their industrial nature and their militant political ambitions. At first, this had been provided by the O.B.U., but the practical example of Bolshevik theory, particularly in the circumstances of the 1919 split, was much more attractive and indeed more suitable. By 1920 the leaders of this group had adopted a position, or rather a state of hopefulness, in line with the instructions of the Third International. ${ }^{1}$ Throughout 1920 , Garden's declarations came under constant A.L.P. and A.W.U. (Australian Workers' Union) attack. In fact, the pro-Bolshevik industrial militants were setting the terms of labour thought. Particularly, they were forcing the A.L.P. on to more radical ground by posing the kind of questions politicians and moderates would have preferred to avoid. The A.L.P. took up moderate attitudes, but on militant questions. It is, in part, in the light of this process that the A.L.P.'s adoption of a Socialisation Objective in 1921 must be seen.

Parallel with the expedient militant industrial trend towards communism, was a doctrinaire political trend in the same direction. This was first manifested in a series of attempts to convert the moderate reformist Victorian Socialist Party of Melbourne into a Communist Party of Australia. From the beginning of 1919, Russian and other militant members of the V.S.P. were becoming increasingly dissatisfied with the pro-A.L.P. attitude of their party. The approach of the I9I9 elections made the issue of whether or not the true socialist should vote A.L.P. a practical question which had to be faced and decided. The issue soon resolved into a clash between R. S. Ross, representing the V.S.P.'s traditional pro-Labor attitude, and the antiLabor stand of those convinced that the Soviet government represented the only successful practical plan for effecting social revolution. ${ }^{2}$

In a surprise move at a policy meeting on 14 January 1920 , communists, led by the Russian J. Maruschak gained acceptance of a motion re-organising the V.S.P. into a Communist Party with appropriate principles and platform. A fortnight later Ross secured a return to traditional V.S.P. lines. ${ }^{3}$ The issue then developed into a prolonged dispute within the party. Ross went to the heart of the

1 O.B.U. (Sydney), Aug. 1920.

2 Socialist, I4, 28 Nov., I 2 Dec. 1919.

3 Victorian Socialist Party Minutes. Special General Meetings, 14, 28 Jan. I920; Socialist, 23 Jan., 6, 13 Feb. I920. 
matter when he summed up the issue as being at bottom a question of socialist attitudes to the A.L.P. His own position was that in a nonrevolutionary Australian situation labour unity was imperative and militants could find both political reality and the chance to implement their ideas, within the A.L.P. The communist position was that in the face of imminent social revolution the A.L.P. was useless and doomed, and would be replaced by the truly revolutionary party, a claim which, as Ross pointed out, was no newer or truer than it had been in 1907, and I9I 2 when militant socialists had taken up similar attitudes to the A.L.P. ${ }^{1}$ There can be no doubt that the major determining factor in the formation of the communist outlook, and later party, among left wing socialist political elements throughout Australia, was hostility to the A.L.P. combined with the conviction that a left wing would never capture it. And this was in spite of an awareness that Lenin and the Comintern favoured communist support of parliamentary labour parties. ${ }^{2}$ Essentially, the political impulse towards communism was a resurgence of that combination of failure, frustration and conviction of ideological superiority which had taken the first socialist vanguard movement, the Australian Socialist League out of the Labor Party in 1898 and had been manifest, on occasion since. In 1920 the ideology was more sophisticated, made sacrosanct by success, but the trend towards communism was nevertheless in the traditional form of A.L.P.-engendered sect.

The V.S.P. dispute, as it continued throughout 1920 , contributed to the rapid polarization of opinion on communism which took place in labour circles throughout that year. Simonoff, as a Bolshevik representative, allowed no criticism of Russia and attacked Ross bitterly. Ross decried force, and condemned the dictatorship of the proletariat as a Bolshevik party tyranny. ${ }^{3}$ Pro-communist opinion was fostered, throughout Australia, by the influence of several Marxist educational and ideological forces. Prominent among these was the Proletarian Review which appeared from June 1920. The Review was ready to accept the lessons of the Bolshevik revolution - mass action and the Soviets - fully as applicable to Australia and accept the guidance of the Third International. Similar doctrines were taught by the Victorian and Sydney Labor Colleges and the Brisbane Workers' School of Social Science. Characteristic of all these educational institutions was their reliance on Marxian texts,

1 Socialist, 23, 30 Jan., I3 Feb. I920.

2 Proletarian, 7 Oct. 1920; The Movement (Brisbane), April, May 1920; Socialist, 20 Feb. 1920.

'Industrial Solidarity (Melbourne), 7 Feb. I920; Socialist, 20 Feb., 5 March 1920. 
their predilection for Russian examples and theorising, their dependence on militant unions for support and their antagonism to the A.L.P. ${ }^{1}$

An important factor contributing towards a formalisation of Bolshevik influence was a change in militant labour's outlook on the world situation. The crisis atmosphere of 19 1 8-19 had gone. For those who had placed their faith in world revolution, there were two alternative ways of facing the future. One was to maintain the world crisis theory. The parliamentarians Considine and Anstey did this, predicting a financial collapse of capitalism which would make way for workers to merely substitute a new social structure. ${ }^{2}$ The other course was to exalt the role of a revolutionary party, a course exemplified by the Bolsheviks. Those who pursued this argument postulated identity between Australian and Russian conditions. As J. Maruschak said, "I do not see any difference at all unless it be one of degree only, and there cannot be any difference of kind under the same capitalist system."3 This allowed them to import, logically, the full paraphernalia of Bolshevik revolution, and to denounce all that was nonBolshevik and Australian, particularly the A.L.P. What this came down to was the doctrine that labour's future stood or fell by Russia and its methods. Fundamentally, this was the issue on which Australian labour had to divide. The defeat of a further communist attempt to capture the V.S.P. in September 1920 led to a sharp and final rift, the communists led by Maruschak and C. W. Baker either leaving the party or being expelled. ${ }^{4}$

That within the V.S.P. was only one of the currents flowing towards the formation of a communist party. The major stream was in Sydney where the A.S.P. opened 1920 with a forthright affirmation of allegiance to the Communist International, and a new, communist, platform. This commitment was the product of a continuing "world crisis" mentality, and the belief that Soviet Russia embodied the living truth of scientific socialism. ${ }^{5}$ More basically, it mirrored the A.S.P.'s wish to climb on the bandwaggon of successful revolution. Its "communism" was narrowly and dogmatically sectarian, critical of "opportunists", industrial actionists, those who wanted soviets, those who wanted revolutionary action, indeed of all which was not A.S.P.

1 Proletarian Review (Melbourne), June, July, Sept. 1920; Socialist, 19 Oct. 1917, 8 Feb. I918; Labor News, 8 May 1920; The Movement, Jan., March 1920; Proletarian, I March 1923.

Socialist, 2, 9 April, 12 Nov. 1920.

Ibid., 9 April rgzo.

- V.S.P. Minutes, Half Yearly Meeting, I Sept. I920, Special Meeting 29 Sept. 1920, Executive Meetings II, 25 Oct., 8, 22 Oct., 12 Nov., Io Dec. 1920.

- International Socialist, ro Jan. I920. 
Of a different kind was the "communism" of the descendants of the I.W.W. The major attraction of the Russian revolution to these antipolitical industrial elements was that it was a violent, successful revolution engineered by a militant minority and issuing in their control. It had succeeded despite, from a Marxian viewpoint, unfavourable circumstances, and had devised, in the soviet, a means to both effect and organise a proletarian revolution. Above all Russia demonstrated the results of direct action. I.W.W. groups took the Russian revolution as confirming their own position, welcoming, as significant in this regard, the fact that the only Australian organisation invited to take part in forming the Communist International was the I.W.W. ${ }^{1}$ To this well-disposed interest was added, in 1920 , recognition of the need for unity among militants. This recognition, in which doctrinal differences were minimised and circumstances and expediency were stressed, sprang not from faith in imminent and inevitable revolutionary crisis, but from awareness that hope of this was passing, and a crisis would have to be made. In a situation apparently pregnant with revolution, correct theory seemed more important than unity, for if revolution was bound to occur, what was most important was to know how to exploit it. The passing of the sense of crisis brought home to various revolutionary groups their isolation and ineffectuality. The movement of I.W.W. groups towards communism, expressed from mid-I 920 in demands for the formation of a Communist party, was both a search for revolutionary unity, and for sustenance and hope from Russian success. ${ }^{2}$

All these tendencies were making for the formation of a Communist Party, but a small group of Sydney Trades Hall industrial militants, led by Garden and W. P. Earsman, had already, secretly, taken the initiative. Early in 1920, this group established a secret Communist Party which worked among unions in terms of "white-anting" through industrial groups. In September this Communist Party appeared openly with a manifesto and call for members. ${ }^{3}$

Stimulated by all these circumstances and pressures, the A.S.P. called a unity conference of all revolutionary socialist organisations and groups in Sydney on 30 October 1920 with the object of forming a united and communist party. ${ }^{4}$ Its formation was followed almost

${ }_{1}$ Proletarian, x Feb., 8, 29 March 1919; Solidarity, is Nov. 1919; Industrial Solidarity, 5, 26 July, 23 Aug., 27 Sept., 22 Nov. 1919.

2 Industrial Solidarity, Feb.-Dec. I920; Toiler (Newcastle), 7 May, 4, I 8 June, 2, 23 July, 20, 27 Aug. 8, 22 Oct. ig Nov, 1920; International Socialist, 9 Oct. 1920; Proletarian, 7 Oct. 1920.

3 Communist (Sydney), 20 May, 23 Sept. 1921 ; International Communist, 19 Nov. 1921 ; International Socialist, 20 Oct. 1920 ; Proletarian, 7 Oct. 1920.

-International Socialist, 6 Nov. 1920 ; Proletarian, 7 Oct., 7 Nov. I 920 ; Socialist, I 2 Nov. 1920 
immediately by a split into A.S.P. and Trades Hall factions, each of which claimed that the other had attempted to capture the conference and dominate the party. While the A.S.P. claimed that the Trades Hall group were heterodox opportunists, the Trades Hall group denounced the A.S.P. as sectarian Left deviationists. ${ }^{1}$ The outcome was two Australian Communist Parties, both claiming to be the Australian section of the Third International. The future of Australian communism was to lie with the Trades Hall party. The A.S.P. group, stressing doctrinal purity and unity, thorough education, and renouncing any "pandering to the workers" isolated itself first into insignificance then oblivion. Its rank and file eventually joined the Trades Hall group to bring about communist unity, under Third International pressures, in June $1922 .{ }^{2}$

The Trades Hall Communist Party was actionist and industrial, proud less of its communism than of its claim to contain "the best revolutionary elements that the Australian working class movement has produced." 3 In traditions, origins, leaders and outlook it was militant industrial, seeing its mission as within the unions. ${ }^{4}$ The Communist Party was, initially, merely another move in the traditional industrial-political battle. But in this conflict, the industrial forces had taken two forms, the anti-political I.W.W. type, and those determined to capture or influence the A.L.P. To begin, the Trades Hall Communist Party contained both these forms, but they fell out over political questions, particularly that of the correct attitude to the A.L.P., and the I.W.W. elements left at the end of 1921 and beginning of $1922 .{ }^{5}$ What remained was a mixture of doctrinaire ideologues and opportunist industrialists. The Garden group sought to use the Communist Party as a method of bringing unionist pressure to bear on the politicians. They were interested in tactics, not doctrines, and to them the Communist Party was like the O.B.U., merely a weapon in a faction fight for power. ${ }^{6}$ Nevertheless, its designs on the A.L.P. were the secret of what success the Communist Party did have. Other socialist

${ }_{1}$ Australian Communist (Sydney), 24 Dec. 1920, 1, 22 April 1921; Communist, 20 May, 24 June I92I ; International Communist (Sydney), I Jan. I 92 I, 24 Sept. 192 I (Supplement).

${ }^{2}$ Communist, 24 Feb., 30 June, 7, 14, 28 July 1922.

s Ibid., 24 June r92 I.

- Australian Communist, 24, 31 Dec., 14, 2 I, 28 Jan., 8 April I921; Communist, I July, 16, 23 Sept. 1921 ; Proletarian, 7 April 1921.

${ }^{5}$ Communist, II, I 8 Nov. 1920; Direct Action (Sydney), I Dec. 1921.

- Communist, 8 July, 4 Aug. 192 I ; International Communist, I 5,29 Oct. 192 I ; Industrialist (Newcastle), ir Aug. 1921; Direct Action, Feb. I922; N.S.W. Trades and Labor Council Minutes, General Meeting I Sept. 1921 ; Australian Labor Party Official Report of Proceedings of the Ninth Commonwealth Conference... Brisbane... October 10, I921..., Melbourne I921, Pp. II. 
sects would have nothing to do with the A.L.P. and perished. The Communist Party at least recognised political reality. It thus survived. The policy of the United Front, taken up by the party early in I922, united the somewhat reluctant ideologues with the opportunists in confirming the already established pursuance of the life-giving truth that the A.L.P. was the mass political party of the working class. ${ }^{1}$

By $192 \mathrm{I}$, the Russian revolution as a vital force in the Australian labour movement had worked itself out, and the Communist Party itself was testimony to that exhaustion. The major impact of the Russian revolution on the labour movement had been to give a vital impulse to radical idealism. A communist observer summed up the militants' reactions in this way:

"Their response to the revolution was the instinctive response of revolutionists to its elemental force rather than the confirmation and fulfilment of a policy they had been consciously pursuing... The volition of the revolution was tremendous. We heard all kinds of cries. 'To hell with education', 'Don't worry about organisation', 'Action is the thing', 'The movement will produce the man, the organisation, the clarity of vision'... These were great days, full of the zest of life..."2

But it was Russian revolution conceived as the promise of world revolution which had Australian relevance and power. Hope for the realisation of a better world could move men's minds and hearts. When this promise and hope was gone, enthusiasm and idealism departed. What was left was the harsh and narrow example of Russia, the concept of a communist party, the impetus to power or advantage, lessons attractive only to opportunists or doctrinaires. The Communist Party may be seen as merely another in a succession of devices which the militant doctrinaire minority had used, since $189 \mathrm{I}$, in their attempts to claim the leadership and control of the labour movement. True, the Communist Party was a new party, but its leaders and their mentality were not. They were men with a past, and of the past. The origins of the Communist Party were deep in factional manoeuvre. It was to be both the great labour sect, and the great sect destroyer. To court it was to risk the kiss of death. Its peculiar, and destructive strength lay in the fact that its confidence and sense of importance were nurtured from outside Australia, yet it was sufficiently related to the A.L.P. to retain a basis in Australian political reality.

1 Communist, 8 July r921, 24 March, 7 April, 5 May, 9 June, 7 July 1922, 5 Jan. I923;

Proletarian, May 1922, I Feb., I March 1923.

2 Proletarian, I June I 923. 
The relative stabilising, in 1922, of the Communist Party, represented the nadir of the revolutionary movement and was in fact tacit recognition that the time for revolution had passed. By the middle of I921, signs of decline were apparent throughout the whole labour movement, and by 1922 the fact that labour was in retreat was inescapably obvious. The elan of the left had gone. World revolution had not occurred, and there was a growing conviction that the Russian revolution had signally failed to fulfil its promise. Russia had not established communism, but had compromised with capitalism. The Russian people were not conscious of any communist objective, starvation was rife. ${ }^{1}$ In Australia labour disunity was as bad as ever.

It is in this context that the A.L.P.'s Socialisation Objective, adopted in $192 \mathrm{I}$, must be considered. The objective was a sign of the exhaustion of the revolutionary impulse, not of its triumph. Of all the avowed revolutionaries, Garden was almost the only one who evinced any enthusiasm for the decisions of the Melbourne Union Congress, which, at the invitation of the A.L.P. executive, adopted a more militant theoretical basis for labour movement unity, centered on a Socialisation Objective. Garden saw these decisions as merely a step by moderates in the right direction, to be welcomed for that reason alone. Among his followers, this assessment had the taint of opportunism. The resemblance of unionist Councils of Action to soviets aroused no enthusiasm among communists who believed that in a non-revolutionary situation soviets would become reactionary. ${ }^{2}$ The Labor Council was suspicious that the Congress was merely another device of the politicians, and the descendants of the I.W.W. were certain it was. $^{3}$ Significantly, the only elements pleased with the Congress were supporters of the A.L.P. and A.W.U. who saw it as a unity measure which could benefit the A.L.P.4 These dispositions were merely intensified by the Brisbane A.L.P. conference which considered, and in large part adopted, the recommendation of the Union Congress, including the Socialisation Objective. Revolutionaries regarded the I92 I A.L.P. conference as a betrayal, even of the insipid decisions of the Congress. In opposing the Socialisation Objective at the conference E. G. Theodore, Queensland's Labor Premier, had said... "one section could go out and say the old obsolete methods were discarded and henceforth they stood as Communists" while the other could "go out

${ }^{1}$ Socialist, I I Nov, I92 I, 27 Jan., 24 Feb., 14 April, I May, I Sept., 2 Oct., 8 Nov. I 922.

2Communist, 8 July r 92 I ; Proletarian, 7 March, 7 July, 7 Aug. I 92 I.

s T. and L. C. Minutes General Meetings, I Sept. I92I; Communist, 30 Sept. r921; Direct Action, I Dec. 1921.

- Worker, I Sept., 6 Oct. 1921 ; Labor News, 2 July I921. 
and say they had simply carried an innocuous term called Socialism". ${ }^{1}$ He was correct in predicting that the objective would be explained away, wrong in thinking it to have been engineered by communists or satisfactory to them. Discerning clearly that it meant no real change in an A.L.P. they hated, the revolutionary left either ignored the Objective or condemned it as a further hypocrisy. ${ }^{2}$ The Brisbane conference was a unity device designed to further the A.L.P's hopes of office. The language in vogue among the powerful industrial elements to be conciliated and won over was that of socialisation. Except among the small forces of the revolutionary left, this language was largely meaningless by $192 \mathrm{I}$, if it had not been so before, but it did represent the dignity and individuality of the unions, as well as a residue of idealism. Socialisation was the vague and remote god to which unionists made their obeisance, and to gain their support the A.L.P. was willing to pay lip service.

The Russian revolution altered the ruling concepts of socialist revolution. The context was still international, but the plan and the leadership were Russian. This constriction choked off many of the former aspirations contained within Australian labour. The dreams of the visionaries dispersed in the face of Russian reality. There was no further room for utopian illusions, at least, not of the former kind. If a few preferred that reality, most saw it as harsh and inhuman. The Russian revolution dealt a grievous blow to both idealism and transmutative socialism as formative forces within Australian labour, an injury all the greater for the hopes which at first revolution had raised. If Russia was socialism, then socialism was in vain. Better to settle for the hum-drum and the second-rate, the politic and the popular.

A similar process of deflation took place within New Zealand labour, but there circumstances were very different. The first Labour Government was not elected until 1935. Since 1907, militant socialists, dedicated to class war and social revolution, had played an important, and in a sense, a vanguard role in the New Zealand labour movement. Their basic tactic was the assertion of leadership in unity arrangements concluded on the terms of non-socialist moderates. The New Zealand Labour Party, formed in 1916 at the initiative of militant socialists, had a socialization objective, but the platform was reformist, and the socialists viewed the party as an emergency device to unify the labour

1 A.L.P. Commonwealth Conference Brisbane 192 I, op. cit., p. I6.

${ }^{2}$ Communist, 28 Oct. 1921; 7 July 1922; International Communist, 22 Oct. I921; Socialist, 28 Oct. I921; Direct Action, I Dec. 1921. 
movement in the face of imminent social revolution. ${ }^{1}$ The Russian revolution had two effects on militant socialists with the N.Z.L.P., one immediate and apparent, the other of long term importance and not immediately obvious. The immediate effect was a partial reversion towards their traditionally doctrinaire position. Up to $192 \mathrm{I}$, the hope of world revolution acted as both spur and inspiration, assisting their claim to a dominant role in the Labour Party. But, at the same time, the militants' political involvements were such as to pose a conflict between ideology and practical politics.

The actual basis of the militant socialists' position within the N.Z.L.P. was unity with the moderates on moderate terms. This was justified, theoretically, as necessary to a policy of preparedness for the social revolution. In practice, the militant socialist leaders of the N.Z.L.P. had adopted the course of working to achieve their ends by constitutional action within the accepted political framework, rather than by waiting for world revolution. Unless social revolution occurred immediately this policy must lead to some thorny problems, and the most fundamental of these was raised by the occurrence of the Russian revolution. It was of crucial importance to militant socialists within the N.Z.L.P. to decide, not only whether or not revolution in Russia was the beginning of world revolution, but, if it was, whether they should support it if that support alienated moderates and prejudiced Labour Party unity. The fact that socialist revolution took root in Russia and not in Germany, where they had expected it, perplexed them and lent to their attitude a considerable degree of caution. ${ }^{2}$ They could not resist being enthusiastic about the Russian revolution, but their succumbing to the temptation was only partial. As to world revolution, they remained hopeful but uncertain, and while they viewed Bolshevik policy with great interest, they held that New Zealand conditions required a different approach. ${ }^{3}$ Their reaction to the Russian revolution was an attempt to make the best of both possibilities, revolutionary and constitutional. They would welcome world revolution, but, cautiously, in case it would not eventuate, they were not prepared to abandon the standards of constitutionalism.

At a fundamental level, the long term effect of the Russian revolution was to force militant socialists within the N.Z.L.P. to abandon their dual position developed during the war, to choose between reliance on hopes of world revolution and the Marxian analysis, and reliance on methods and policies which not only labour moderates, but the

1 P. J. O'Farrell, The Formation of the New Zealand Labour Party, in: Historical Studies Australia and New Zealand, Vol. 10, No. 38, May I962, pp. 190-202.

Maoriland Worker(Wellington, N.Z.), 16 Oct. I918.

3 Ibid., I I Aug. 1920. 
majority of the electorate would accept and support. They chose - or rather found themselves committed to - the practical gradualism of the moderates. What had formerly been a static policy of preparedness for a postulated capitalist collapse, had gradually become an active method of working towards social transformation in a democratic constitutional context. This development profoundly affected the militant socialists' role within the N.Z.L.P. for it meant a re-definition in essentially non-revolutionary terms, of the aims towards which socialist leadership had hitherto been directed. The decline of militant socialist leadership and influence within the N.Z.L.P. dates from the period I9I 8-2I when these socialists refused to admit, save in the most general way, the relevance of the Russian revolution.

Within Australian labour, the early years of Bolshevik power represent something of a turning point. Utopian hopes and idealism, humanitarian visions and dreams, so much part of labour's tradition and impetus, were expanded to their greatest extent, only to die away frustrated. The era of the romantic revolutionary, in so far as it had existed, ended abruptly. In New Zealand the Russian revolution, by posing the alternative between revolution and reform, merely demonstrated that among the strongest militant socialist element, the choice had already, if perhaps unconsciously, been made. The revolution did not so much create a situation, as in Australia, as clarify an existing one. The leaders of New Zealand socialism had already experienced too many false revolutionary alarms to be sanguine about another.

The Russian revolution resulted in the formation of a New Zealand Communist Party at the end of 1920 . Its development, springing from the belief that the N.Z.L.P. was insufficiently revolutionary, was most gravely inhibited by the fact that the N.Z.L.P. had never held office. Unlike the A.L.P., the N.Z.L.P's revolutionary potential had never been tested by governmental opportunity. Furthermore, the militant socialist tradition within New Zealand labour was contained within the N.Z.L.P. When a new group of industrial militants emerged from the post-war ferment, their position was anti-political rather than procommunist.

The rootless isolation of the New Zealand Communist Party suggests an element in the appeal of the Russian revolution which is less discernable in the more complex Australian situation. It was a new revolution and its adherents were a new generation. Was the Russian revolution to sum up the aspirations of the old generation of socialists, or was it to provide plans for a new? It is of fundamental significance that the Third International issued the New Communist Manifesto. 
The socialist tradition in Australia and New Zealand was represented by men in their fifties. In 1920, H. E. Holland, the militant socialist leader of the N.Z.L.P. was fifty-two. S. W. Scott who moved the motion to form the first New Zealand Communist Party branch was twenty. R. S. Ross defended the "Old Show" of the V.S.P. against communists who demanded it be brought up-to-date. The Russian revolution provided an issue and a plan for the conflict between two generations of radicals. New Zealand labour proved comparatively resistant to the divisive influence of the Russian challenge because the older generation had only just begun their efforts to gain parliamentary power. In Australia, the performance of the A.L.P. governments since I9I0, and particularly the conscription split, had discredited the first generation of radicals - and their brand of radicalism - in the eyes of those not of that generation. It was in this bitter ferment that Russia and its revolution seemed, for a time, relevant. 